Canadian Studies in Population, Vol. 30(1), 2003, pp. 51-69

\title{
The Pure Relationship and Below Replacement Fertility
}

\author{
David R. Hall \\ Department of Sociology \\ Nipissing University \\ North Bay, Ontario \\ Professional Associate \\ Population Studies Centre \\ University of Western Ontario \\ London, Ontario
}

\begin{abstract}
Of the many changes which have characterized the second demographic transition, shifts in fertility and union formation have attracted a great deal of interest from demographers. Despite the fact that researchers have extensively modeled recent demographic changes such as skyrocketing divorce rates, rising common-law union formation, delayed childbearing, and the decline to belowreplacement fertility levels, our understanding of the causes of these trends, and the possible connections between them remains theoretically fragmented and incomplete. The goal of this paper is to advance our understanding in this area by exploring the insights on modern family formation of prominent sociologist Anthony Giddens. Specifically, this study examines whether Giddens" "pure relationship" concept can shed light on the trend toward very low fertility. The results of this inquiry suggest that couples in both marriages and common-law unions who conform to key aspects of Giddens pure relationship are more likely to have uncertain or below-replacement fertility intentions, and less likely to embrace above-replacement fertility goals.
\end{abstract}

Key Words: Fertility, pure relationships, Anthony Giddens, family formation, risk, second demographic transition 


\section{Resumé}

Of the many changes which have characterized the second demographic transition, shifts in fertility and union formation have attracted a great deal of interest from demographers. Despite the fact that researchers have extensively modeled recent demographic changes such as skyrocketing divorce rates, rising common-law union formation, delayed childbearing, and the decline to belowreplacement fertility levels, our understanding of the causes of these trends, and the possible connections between them remains theoretically fragmented and incomplete. The goal of this paper is to advance our understanding in this area by exploring the insights on modern family formation of prominent sociologist Anthony Giddens. Specifically, this study examines whether Giddens' "pure relationship" concept can shed light on the trend toward very low fertility. The results of this inquiry suggest that couples in both marriages and common-law unions who conform to key aspects of Giddens pure relationship are more likely to have uncertain or below-replacement fertility intentions, and less likely to embrace above-replacement fertility goals.

Mots-clés: Fertility, pure relationships, Anthony Giddens, family formation, risk, second demographic transition

\section{Introduction}

In recent decades demographers have documented a number of dramatic changes in social-demographic behavior in the more industrialized, democratic societies. More directly, unprecedented shifts in family formation such as increased cohabitation, divorce, and non-marital fertility, a rising age at first marriage and first childbirth, and fertility declines too well-below population replacement levels, have been described as a "second demographic transition" by Dirk Van de Kaa (1987) and Ron Lesthaeghe (1995). Not surprisingly, among the changes which have attracted the greatest interest from demographers are those involving union formation and dissolution, and declining fertility.

While this interest among demographers has produced several suggestive theories and powerful statistical models, it is fair to state that demography has been less successful at integrating data, models, and theory dealing with transformations in family formation. This shortcoming is what inspired Ron Lesthaeghe to recently call for a new theoretical approach to the study of family formation... a multicausal and synthetic approach (Lesthaeghe, 1998: 7-8). 
In response, the main purpose of this paper is to outline and apply some of the central sociological concepts of Anthony Giddens, concepts which hold much promise as a basis for generating a more synthetic and complete understanding of modern family demographic behavior. Specifically, the focus of this paper is on exploring the connection between what Giddens has called the "pure relationship" and low levels of fertility in Canada.

\section{Plastic Sexuality and the Pure Relationship}

One of the key transformations that has accompanied modernization is the growing separation of sexuality from the exigencies of reproduction. Although Giddens (1992) asserts that the process started with the demographic transition in Europe, the separation of sexuality and reproduction has accelerated enormously in recent decades with rapid innovations in contraceptive and reproductive technologies.

In western societies today, sexuality has not only been largely disconnected from reproduction, but from patriarchal, religious, and normative controls as well. Unlike traditional societies where sexuality was anchored to social norms, customs, roles, and institutions such as religion and marriage; sexuality in modern society has become something that is defined and "moulded" by an individuals as an expression of their individual personality and lifestyle (Giddens, 1992:1-17). Indeed, Giddens (1992) describes modern sexuality as "plastic sexuality", and argues that its primary purpose is to serve as a malleable vehicle for self-expression and self-actualization.

The emergence of plastic sexuality is important to demographers because it has given rise to profound changes in intimate relationships. In particular, the separation of sexuality and reproduction has triggered a parallel separation of marriage and parenthood (Giddens, 2000:69-84). As Mills (2000) argues, the growing number of childless couples and single parents demonstrate that marriages and common-law unions are no longer established or sustained primarily for reproductive reasons. Rather, contemporary marriages and consensual unions are increasingly centred on the couple, and incorporate many of the features which Giddens has detailed with his concept of the pure relationship (Giddens, 1992:49-65).

The pure relationship is an ideal type, which like all ideal types in the social sciences, is designed to provide an abstract standard or referent that isolates and describes the most salient and defining characteristics of some social phenomenon. In the case of the pure relationship, Giddens has theorized the salient and defining features of modern intimate relationships. 
David R. Hall

\section{The Pure Relationship and Fertility}

For the purposes of this study, Giddens' pure relationship construct includes a number of qualities that are relevant to fertility behavior. To begin with, pure relationships are organized and sustained by the couple themselves. That is to say, pure relationships are not materially anchored to external social phenomenon such as extended family, community, religion, or traditional roles, customs, and norms. On the contrary, pure relationships are voluntarily and internally organized and maintained by the couple themselves (Giddens, 1991:88-89).

Second, pure relationships are not just internally constituted, but reflexively organized by the couple. Essentially, this means that very little about pure relationships can be "taken-for-granted" by the partners for very long. Instead, both partners in a pure relationship routinely monitor and reflect on the relationship against a backdrop of alternative relational possibilities and choices conveyed to them mainly through various mass media. Importantly, subsequent relational modifications arising from this monitoring contribute to the ongoing or reflexive maintenance of pure relationships (Giddens, 1991:91-92)

Third, as Hall (1996) has elaborated on, the fact that pure relationships are internally and reflexively organized and sustained makes them well-suited to the pace and scope of modern social change. Specifically, the structure of pure relationships makes them, in principle, more egalitarian, democratic, and flexible than traditional marital forms.

Giddens holds that these qualities of pure relationships have combined to transform intimate relationships into sites for self-actualization. Accordingly, the educational and labour force interests of both partners are more equally relevant to the relationship. Likewise, plastic sexuality is more fully realized within the pure relationship since the sexual satisfaction of both partners is salient. More generally, the pure relationship serves as an environment or context for the development and expression of the individual identity of the partners (Giddens, 1991:89-98).

In this sense, Giddens pure relationship represents a valuable and natural extension of Lesthaeghe and Surkyn's (1988) thesis that an ideational shift toward secular individualism and self-actualization underlies the second demographic transition.Pursuing the issue further, Beck and Beck-Gernsheim (1995) have described how growing individualism has rendered cohabitation and marriage "empty social categories" that couples must "fill" themselves. Specifically, individuals who want to live together today must negotiate, define, and justify the characteristics of their relationship on an ongoing basis. And 
while this tends to make modern intimate relationships more democratic and egalitarian, it also makes them more risky and unpredictable.

Giddens $(1992 ; 2000)$ reinforces this point by asserting that the same features of pure relationships that make them democratic, egalitarian, and sites for selfactualization, also make pure relationships inherently unstable and risky. More directly, their "open-ended requirements" and lack of external social anchors all but ensures that pure relationships are intrinsically more contingent than traditional unions. And not the least of the many things which cannot be taken for-granted in pure relationships is their longer-term viability. Pure relationships impart ongoing and substantial demands on the empathy, integrity, and self-awareness of the partners. Consequently, the relationships carry enormous built-in risk of dissatisfaction, distrust, and dissolution (Giddens, 1991:88-98; 185-187; 1992:134-156).

Furthermore, the reflexive nature of pure relationships means that both partners are aware that the relationship can be terminated by either partner at any time. As Giddens (1990) explains, anyone contemplating marriage or cohabitation in western societies will be aware to some degree of the high risk of dissolution or divorce, and will have calculated in the context of bounded rationality, the odds or risk that their relationship could end. This reflexive risk assessment, or what is referred to as the "risk profile" of the relationship, is typically grounded in some combination of experiential and media derived information, criteria, or research involving family relationships (Giddens, 1991:109-143). Needless to say, the risk profile which partners attach to an intimate relationship will itself reflexively influence the organization of the relationship.

From a demographic perspective, the major implication of these features is that childbearing or fertility behavior is not an intrinsic element of pure relationships. On the contrary, childbearing and childrearing are likely to be viewed as an "externality" or possible threat to the relationship unless fertility behavior is seen as contributing to the self-actualization of both adult partners. It follows that a pure relationship with a higher "risk profile" attached to it by the partners is more likely to regard having children as an externality or potential drag on possible dissolution, and an obstacle to partner self-actualization (Giddens, 1991:185-187). Indeed, this connection is especially likely in view of the growing perception in modern society that childbearing and childrearing are risky activities, particularly in the context of relationships at high risk of dissolution (Lupton, 1999a:59-85; Jackson and Scott, 1999:86-107; Wallerstein, 2000). 
David R. Hall

\section{Hypotheses}

On the strength of Giddens' theory and concepts regarding family formation, two hypotheses on the link between the pure relationship and low levels of fertility were derived:

(1) To the extent that individuals support egalitarian intimate relationships, they are signaling that these unions approximate pure relationships. Accordingly, relational egalitarianism will be associated with lower fertility intentions.

(2) The higher the "risk profile" that individuals attach to their intimate relationships, the more likely it is that they perceive these as pure relationships where fertility behavior is a potential threat to selfactualization. Therefore, a higher risk profile for unions will be associated with lower fertility intentions.

\section{Data and Methods}

The data employed in this study are from the 1995 Canadian General Social Survey (GSS-95). The GSS-95 was conducted by Statistics Canada and involved a national probability sample of 10,749 respondents aged 15 or older (5,914 females and 4,835 males). In this survey, telephone interviews were used to compile detailed information on marriage and the family including respondent marital and family histories, reproductive intentions, and family-related attitudes and values.

Since the theoretical focus of this research was on the reproductive intentions, attitudes, and values of the spousal unit, the analysis was restricted to zeroparity, heterosexual couples currently living in a marital or common-law union. As well, the study sample was limited to respondents who had no children from prior relationships, were not currently pregnant, and had no medical reason to prevent them from having children. Finally, to minimize the effect of agerelated subfecundity, the female partner's in the study sample included only those respondents who were age 40 or younger at the time of the survey.

To ensure proper specification of the statistical models, all standard predictors of fertility that have been included and rationalized in previous research were incorporated in this study (Radecki and Beckman, 1992; Thornton, Axinn, and Hill, 1992; Hirshman, 1994; Wu and Wang, 1998). As is shown in Table 1, respondent work status, religious affiliation, province of residency, place of birth, sex, marital status, and age heterogamy of the spousal unit were all included in the analysis and measured as dummy variables. Regarding age heterogamy, the effect of having a male partner three or more years older was 
Table 1

Definitions and Descriptive Statistics for Explanatory Variables Used in the Analysis of Fertility Intentions for Canada, 1995

\begin{tabular}{|c|c|c|}
\hline Variable & Definition & Mean or $\%$ \\
\hline \multicolumn{3}{|l|}{ Socioeconomic Status: } \\
\hline Working & $\begin{array}{l}\text { Dummy indicator of respondent's current employment } \\
\text { status ( } 1=\text { Not working, } 0=\text { Working) }\end{array}$ & $15.2 \%$ \\
\hline Income & $\begin{array}{l}\text { Respondent's income in } 12 \text { increments } \\
(1=\text { none }, \ldots \ldots, 12=\$ 100,000 \text { or more })\end{array}$ & 5.9 \\
\hline Education & $\begin{array}{l}\text { Respondent's education in } 6 \text { increments } \\
(1=\text { less than high school, } \ldots, 6=\text { university graduate })\end{array}$ & 3.8 \\
\hline \multicolumn{3}{|l|}{ Cultural Background: } \\
\hline Non-Catholic & $\begin{array}{l}\text { Dummy indicator of religious affiliation } \\
(1=\text { non-Catholic, } 0=\text { Catholic })\end{array}$ & $52.3 \%$ \\
\hline Secularism & $\begin{array}{l}\text { Attendance at church services in } 5 \text { increments } \\
(1=\text { at least once a week, }, \ldots, 5=\text { not at all })\end{array}$ & 3.5 \\
\hline Quebec resident & $\begin{array}{l}\text { Dummy indicator of Quebec residency } \\
(1=\text { Yes, } 0=\text { No })\end{array}$ & $28.7 \%$ \\
\hline Born outside of Canada & $\begin{array}{l}\text { Dummy indicator of respondent's country of birth } \\
(1=\text { Yes, } 0=\mathrm{No})\end{array}$ & $12.7 \%$ \\
\hline \multicolumn{3}{|l|}{ Demographics: } \\
\hline Male & $\begin{array}{l}\text { Dummy indicator of respondent's sex } \\
(1=\text { male, } 0=\text { female })\end{array}$ & $42.6 \%$ \\
\hline Age & Age of respondent & 29.3 \\
\hline Common-Law Union & $\begin{array}{l}\text { Dummy indicator of current marital status } \\
(1=\text { Common Law, } 0=\text { Married })\end{array}$ & $42.8 \%$ \\
\hline $\begin{array}{l}\text { Age at current union } \\
\text { Age heterogamy }\end{array}$ & Age of respondent at start of current union & 26.1 \\
\hline Husband Older & $\begin{array}{l}\text { Dummy indicator that husband is } 3 \text { or } \\
\text { more years older }(1=\text { Yes, } 0=\text { No) }\end{array}$ & $36.2 \%$ \\
\hline Wife Older & $\begin{array}{l}\text { Dummy indicator that wife is } 3 \text { or more } \\
\text { years older }(1=\text { Yes, } 0=\text { No) }\end{array}$ & $5.8 \%$ \\
\hline Similar Age & Reference category & \\
\hline $\begin{array}{l}\text { Siblings } \\
\text { Pure Relationship Indices: }\end{array}$ & \multicolumn{2}{|c|}{ Pure Relationship Indices: } \\
\hline Relational egalitarianism & $\begin{array}{l}\text { Index measuring egalitarian gender roles in } 20 \text { increments } \\
(1=\text { inegalitarian }, \ldots \ldots \ldots \ldots, 20=\text { egalitarian })\end{array}$ & 10.8 \\
\hline Union Risk Profile & $\begin{array}{l}\text { Index measuring contingency of marital or common-law } \\
\text { relationships in } 11 \text { increments }(1=\text { low, } \ldots \ldots, 11=\text { high })\end{array}$ & 5.8 \\
\hline Total Number of Cases (un & & $\mathrm{N}=575$ \\
\hline
\end{tabular}


captured with the dummy variable "husband older", while the impact of having a female partner three or more years older was measured with the variable "wife older". The reference category for both dummy variables was "spouses of similar age" or relationships where both partners are within two years of age of each other.

Turning our attention to continuous covariates that predict fertility in the research literature, respondent annual income was ordinally measured with a 12 increment. Also, respondent educational attainment was measured along a 6 increment ordinal scale ranging from 1 for those with less than high school to 6 for university graduates. Attendance at religious services served as a proxy for secularism in this study and varied from a 1 for respondents who attended church at least once a week, to 5 for those who never attended formal church services. Finally, the age of the respondent at the time of the survey, and the age of the respondent at the start of the current marriage or common-law union were both measured in years, while the number of siblings that the respondent grew up with was included as a measure of early fertility socialization.

Of course, the thrust of this study was on operationalizing Giddens' "pure relationship" for testing as a predictor variable of fertility intentions. In this regard, the GSS-95 included several promising empirical indicators. Specifically, Table 2 reports the survey questions that were combined to form an index measuring relational egalitarianism. It should be noted that the composite index constructed by summing these 6 Likert items is similar to an index employed by $\mathrm{Wu}$ and Wang (1998) in their analysis of third births in Canada. However, since the theoretical concerns of this study differ from $\mathrm{Wu}$ and Wang's research, a different configuration of the survey items was used in order to maximize the face validity of the index measuring relational egalitarianism.

The second composite indicator developed to operationalize pure relationships was a union risk profile index. This risk profile index was formed by summing the dichotomous responses to the survey items listed in Table 3. As can be seen, these items query respondents on whether a marriage or common-law union should be terminated under various scenarios. Other things equal, it can be assumed that a higher score on the risk profile index translates into a greater tolerance for contingent intimate relationships, and respondent awareness of a high probability that the current union could end in dissolution.

The Cronbach's alpha for the relational egalitarianism index was .55, while thereliability coefficient for the risk profile index was .71. Overall, the two indices developed to operationalize pure relationships are both reasonably reliable and content or face valid.

The dependent variable in this research was the intended fertility of the respondent. While fertility intention is not a perfect predictor of eventual 
Table 2

Percentage Distribution of Pure Relationship Indicators 1:

Relational Egalitarianism Questions for Canada, 1995

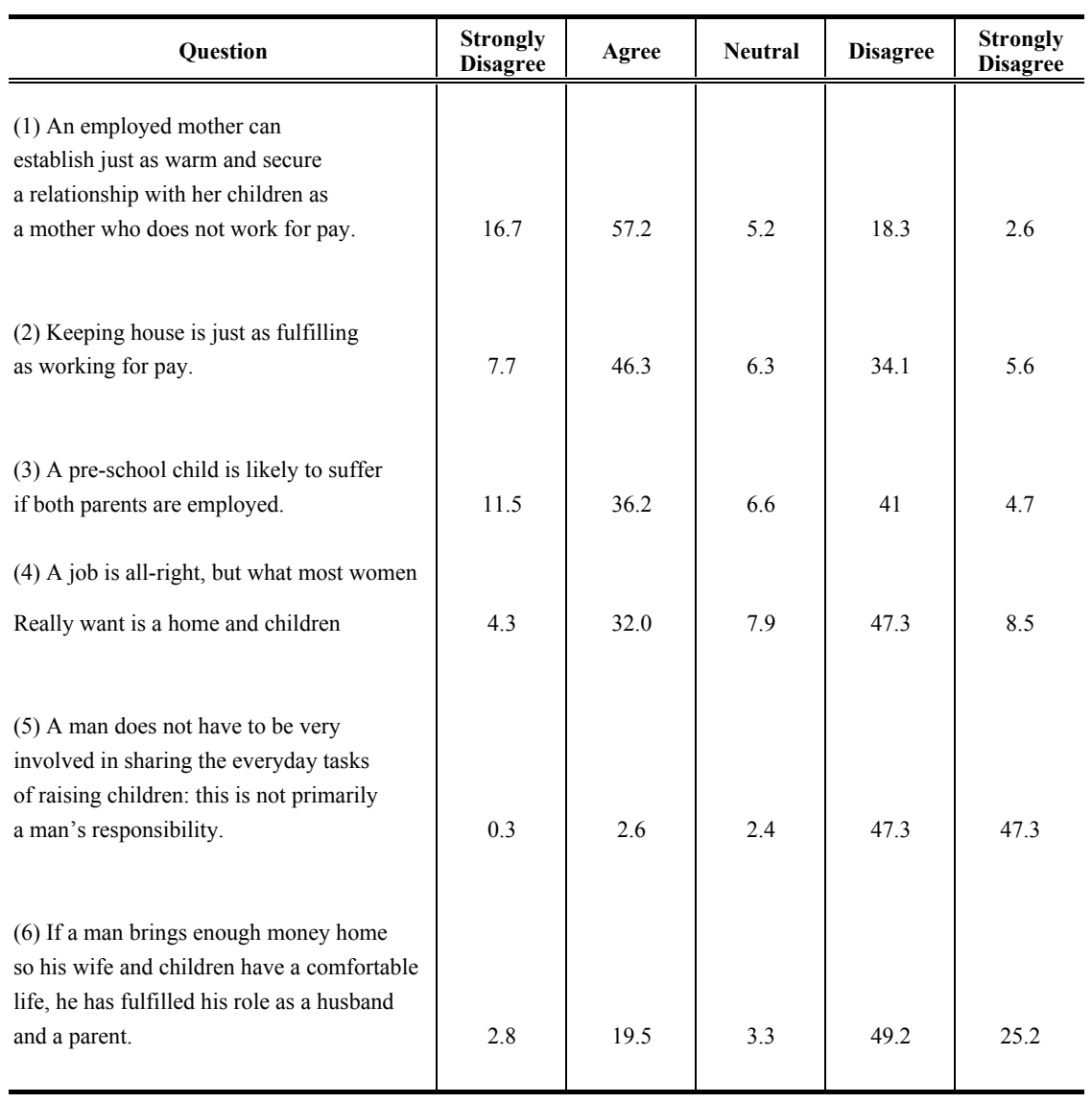

Note: Neutral includes respondents who answer "don't know" and "no opinion." 
Table 3

Percentage Distribution of Pure Relationship Indicators 2: Union Risk Profile Questions for Canada, 1995

\begin{tabular}{|c|c|c|c|}
\hline Indicators & Yes & No & $\begin{array}{l}\text { Do Not } \\
\text { Know }^{1} \\
\end{array}$ \\
\hline \multicolumn{4}{|l|}{$\begin{array}{l}\text { Please tell me if you think the following reasons are sufficient for } \\
\text { splitting up a marriage or common-law relationship: }\end{array}$} \\
\hline (1) Partner drinks too much. & 66.6 & 26.1 & 7.3 \\
\hline (2) Lack of love and respect from partner & 89 & 7.3 & 3.7 \\
\hline $\begin{array}{l}\text { (3) Constant disagreement about how the } \\
\text { family finances are handled. }\end{array}$ & 36.9 & 58.6 & 4.5 \\
\hline (4) Abusive behavior from the partner. & 92.9 & 4.2 & 2.9 \\
\hline $\begin{array}{l}\text { (5) Unsatisfactory division of household } \\
\text { tasks. }\end{array}$ & 14.3 & 81.6 & 4.1 \\
\hline (6) Unfaithful behavior from partner. & 86.1 & 9.2 & 4.7 \\
\hline $\begin{array}{l}\text { (7) Unsatisfactory sexual relationship with } \\
\text { partner. }\end{array}$ & 30.3 & 62.8 & 6.9 \\
\hline (8) Inability to have children with partner. & 8.3 & 86.1 & 5.6 \\
\hline $\begin{array}{l}\text { (9) Disagreement about the number of } \\
\text { children to have. }\end{array}$ & 5.4 & 91 & 3.6 \\
\hline $\begin{array}{l}\text { (10) Conflict about how the children are } \\
\text { raised. }\end{array}$ & 13.9 & 77.6 & 8.5 \\
\hline
\end{tabular}

Note: ${ }^{1}$ Includes respondents who did not state a response 
fertility behavior, a number of studies indicate that intended fertility is a valid predictor of subsequent fertility behavior (Boongaarts, 1992; Tan and Tey, 1994; Thomson and Hoem, 1996).

As Table 4a and Table 4b illustrate, the dependent variable was recoded from continuous responses into a polytomous variable with four categories. With this recoding, four logits were formed using the fourth category as a baseline or reference category. For this study, respondent intent to have exactly two children, or replacement-level fertility, was selected as the reference category. While the selection of the reference category is to some extent always arbitrary, the percentage distribution of the dependent variable confirms that this remains the normative fertility goal in Canada with nearly one-half of the study sample expressing replacement-level fertility intentions. Accordingly, replacement level fertility seems to be the most useful and least arbitrary standard for the goals of this research.

\section{Results and Conclusions}

With a polytomous dependent variable, multinomial logistic regression was employed in order to estimate a series of contrasting models. More directly, statistical models for three contrasts to the reference category were estimated:

1. Uncertain versus replacement fertility intentions.

2. Below-replacement versus replacement fertility intentions.

3. Above-replacement versus replacement fertility intentions.

Looking at the first contrast, Table 5 shows the exponentiated beta parameters for the logit models comparing uncertain with replacement fertility intentions. The exponentiated beta's measure the impact of a predictor variable on the odds of giving a specifed response compared to the reference response.... which in this case was an intent to have two children

The results from the fully specified model 5 reveal that, compared to the nreference group, respondents who are uncertain about their future childbearing tend to be less educated and younger when they began their current union. Interestingly, net of the other covariates in model 5, respondents become more uncertain about future fertility behavior as they grow older. This finding could reflect a tendency for unions to become more couple-centered as the partners in a childless relationship grow older. Also, consistent with Giddens' thesis that childbearing is not an inherent aspect of pure relationships, higher relational egalitarianism significantly increases the odds of being uncertain about future childbearing. On the other hand, the results from model 5 suggest that the risk profile respondents attach to intimate relationships has no impact on fertility 
Table 4a

Fertility Intentions of Parity 0 Couples for Canada, 1995

\begin{tabular}{lcc}
\hline $\begin{array}{l}\text { Number of Children } \\
\text { Intends to Have: }\end{array}$ & Frequency & Percentage \\
& & \\
\hline & & \\
None & 96 & 16.7 \\
One & 44 & 7.7 \\
Two & 277 & 48.2 \\
Three & 70 & 12.2 \\
Four & 23 & 4.0 \\
Five or more & 3 & 0.5 \\
Do not know & 56 & 21 \\
$\quad$ Total & 569 & 99.0 \\
\hline
\end{tabular}

Table 4b

Recorded Fertility Intentions of Parity 0 Couples for Canada, 1995

\begin{tabular}{ccc}
\hline Fertility Intentions & Frequency & Percentage \\
\hline Below Replacement Level & 140 & 24.3 \\
Replacement Level ${ }^{1}$ & 277 & 48.2 \\
Above Replacement Level & 96 & 16.7 \\
Uncertain & 56 & 9.7 \\
Total & 569 & 99.0 \\
\hline Reference group in multinomial logistic & regression models.
\end{tabular}


Table 5

Multinomial Logistic Regression Models for Fertility Intentions, Uncertain Intentions vs. Replacement Intentions for Canada, 1995

\begin{tabular}{|c|c|c|c|c|c|}
\hline Independent Variables & Model 1 & Model 2 & Model 3 & Model 4 & Model 5 \\
\hline \multicolumn{6}{|l|}{ Socioeconomic Status : } \\
\hline Work Status & & & & & \\
\hline Not working outside the home & 1.438 & & & & 1.716 \\
\hline Income & 1.128 & & & & 1.218 \\
\hline Education & 0.926 & & & & $.688^{* * *}$ \\
\hline \multicolumn{6}{|l|}{ Cultural Background : } \\
\hline Non-Catholic & & 0.684 & & & 0.633 \\
\hline Secularism & & 1.197 & & & 1.055 \\
\hline Quebec Resident & & 1.043 & & & 1.444 \\
\hline Born outside Canada & & 0.746 & & & 0.351 \\
\hline \multicolumn{6}{|l|}{ Demographics: } \\
\hline Male & & & $.397^{* * *}$ & & 0.548 \\
\hline Age of respondent & & & $1.231 * * *$ & & $1.261^{* * *}$ \\
\hline Common-Law Union & & & 1.208 & & 0.633 \\
\hline Age at Current Union & & & 0.913 & & $.867^{* * *}$ \\
\hline \multicolumn{6}{|l|}{ Age heterogamy } \\
\hline Husband Older & & & 1.151 & & 1.49 \\
\hline Wife Older & & & 0.409 & & 0.44 \\
\hline Number of Siblings & & & 1.066 & & 1.064 \\
\hline \multicolumn{6}{|l|}{ Pure Relationship Indicators : } \\
\hline Relational egalitarianism & & & & $1.108 * *$ & $1.243^{* * *}$ \\
\hline Union Risk Profile & & & & 1.04 & 1.071 \\
\hline Intercept & $-2.086^{* *}$ & $-2.180^{* *}$ & $-5.290 * * *$ & $-4.025^{* * *}$ & $-9.741 * * *$ \\
\hline \multicolumn{6}{|l|}{ Likelihood Ratio } \\
\hline Chi-Square & 27.12 & 20.63 & 188.496 & 22.148 & 226.526 \\
\hline (df) & (9) & (12) & $(21)$ & (6) & (48) \\
\hline
\end{tabular}

$* * * \mathrm{p}<.01 \quad * * \mathrm{p}<.05 \quad * \mathrm{p}<.10$ 
uncertainty. The research expectation was that a risk index measuring the contingency of intimate relationships would also generate uncertainty about childbearing goals.

The same surprising outcome can be seen in Table 6 . This table summarizes the effects of predictors on the odds that a respondent would express belowreplacement compared to replacement fertility intentions (no children or one child versus two children). In the fully specified model 5 , the pure relationship indicator of relational egalitarianism increased the odds of below replacement fertility preferences. In particular, every one unit increase in the index operationalizing relational egalitarianism increased the odds of a respondent expressing below replacement fertility intentions by $14 \%$.

Briefly shifting attention to other predictors, respondent age, Quebec residency, and a husband three or more years older than the wife were also notable predictors of below replacement fertility desires.

In contrast, male respondents were less likely than females to exhibit belowreplacement childbearing goals. As well, couples with a partner not working outside the home, respondents born outside of Canada, better educated respondents, and couples who were older at the start of their current relationship, were less likely to indicate below-replacement than replacement fertility preferences.

Finally, Table 7 contrasts above-replacement (three or more children) withreplacement-level fertility objectives. Looking at the complete model (model 5), it is evident that work status has a very strong impact on the dependent variable. More directly, couples with a partner not working outside the home were three times more likely than couples with both partners working, to have above-replacement childbearing goals. Net of the other predictors, increased formal education also improved the odds of wanting three or more children.

On the other side of the coin, respondent age, and both pure relationship indices significantly reduced the probability of a person desiring three or more children rather than two. Importantly, the strongest negative effect on intended fertility came from the index measuring the union risk profile. In particular, every one unit increase in the risk profile index reduced the odds of embracing abovereplacement fertility preferences by nearly $25 \%$.

To sum up, the findings from this study indicate that a key component of Giddens' ideal typical pure relationship, namely the egalitarian structure of pure relationships, increases the chances of having uncertain or below-replacement fertility goals, and reduces the odds of holding above-replacement childbearing intentions. Furthermore, while the risk profile of pure relationships does not 
Table 6

Multinomial Logistic Regression Models for Fertility Intentions, Uncertain Intentions vs. Replacement Intentions for Canada, 1995

\begin{tabular}{|c|c|c|c|c|c|}
\hline Independent Variables & Model 1 & Model 2 & Model 3 & Model 4 & Model 5 \\
\hline \multicolumn{6}{|l|}{ Socioeconomic Status : } \\
\hline Work Status & & & & & \\
\hline Not working outside the home & .591 & & & & $.331^{*}$ \\
\hline Income & 1.034 & & & & .900 \\
\hline Education & .958 & & & & $.777^{* *}$ \\
\hline \multicolumn{6}{|l|}{ Cultural Background : } \\
\hline Non-Catholic & & 1.513 & & & 1.300 \\
\hline Secularism & & $1.226^{*}$ & & & 1.193 \\
\hline Quebec Resident & & $2.061 * *$ & & & $2.222 * *$ \\
\hline Born outside Canada & & .749 & & & $.277^{* *}$ \\
\hline \multicolumn{6}{|l|}{ Demographics: } \\
\hline Male & & & $.378 * * *$ & & $.397 * * *$ \\
\hline Age of respondent & & & $1.308 * * *$ & & $1.326^{* * *}$ \\
\hline Common-Law Union & & & 1.386 & & .831 \\
\hline Age at Current Union & & & $.881^{* * *}$ & & $.872 * * *$ \\
\hline \multicolumn{6}{|l|}{ Age heterogamy } \\
\hline Husband Older & & & $1.867 * * *$ & & $2.354 * * *$ \\
\hline Wife Older & & & 1.280 & & $1.55+.972$ \\
\hline Number of Siblings & & & .994 & & 1.064 \\
\hline \multicolumn{6}{|l|}{ Pure Relationship Indicators : } \\
\hline Relational egalitarianism & & & & $1.060^{*}$ & $1.140^{* * *}$ \\
\hline Union Risk Profile & & & & 1.048 & 1.078 \\
\hline Intercept & -.671 & $-1.873^{* * *}$ & $-5.494 * *$ & $-2.191 * *$ & $-7.938 * * *$ \\
\hline \multicolumn{6}{|l|}{ Likelihood Ratio } \\
\hline Chi-Square & 27.12 & 20.630 & 188.496 & 22.148 & 226.526 \\
\hline (df) & (9) & (12) & $(21)$ & $(6)$ & (48) \\
\hline
\end{tabular}

$* * * \mathrm{p}<.01 \quad * * \mathrm{p}<.05 \quad * \mathrm{p}<.10$ 
Table 7

Multinomial Logistic Regression Models for Fertility Intentions, Above Replacement vs. Replacement Intentions for Canada, 1995

\begin{tabular}{|c|c|c|c|c|c|}
\hline Independent Variables & Model 1 & Model 2 & Model 3 & Model 4 & Model 5 \\
\hline \multicolumn{6}{|l|}{ Socioeconomic Status : } \\
\hline Work Status & & & & & \\
\hline Not working outside the home & $.1 .843^{*}$ & & & & $3.008 * * *$ \\
\hline Income & .890 & & & & 1.059 \\
\hline Education & 1.104 & & & & $1.250 * *$ \\
\hline \multicolumn{6}{|l|}{ Cultural Background : } \\
\hline Non-Catholic & & 1.162 & & & .933 \\
\hline Secularism & & .933 & & & 1.086 \\
\hline Quebec Resident & & 1.745 & & & 1.670 \\
\hline Born outside Canada & & 1.023 & & & 1.287 \\
\hline \multicolumn{6}{|l|}{ Demographics: } \\
\hline Male & & & .833 & & .716 \\
\hline Age of respondent & & & $.879 * *$ & & $.905^{*}$ \\
\hline Common-Law Union & & & .883 & & .744 \\
\hline Age at Current Union & & & 1.041 & & 1.006 \\
\hline \multicolumn{6}{|l|}{ Age heterogamy } \\
\hline Husband Older & & & .821 & & .747 \\
\hline Wife Older & & & .376 & & .420 \\
\hline Number of Siblings & & & 1.078 & & 1.029 \\
\hline \multicolumn{6}{|l|}{ Pure Relationship Indicators : } \\
\hline Relational egalitarianism & & & & 0.964 & $.903 * *$ \\
\hline Union Risk Profile & & & & $.868 * *$ & $.769^{* * *}$ \\
\hline Intercept & $-.916^{*}$ & $-.934 * *$ & $-1.464 *$ & .487 & $3.616^{* * *}$ \\
\hline \multicolumn{6}{|l|}{ Likelihood Ratio } \\
\hline Chi-Square & 27.12 & 20.63 & 188.496 & 22.148 & 226.526 \\
\hline (df) & (9) & (12) & (21) & (6) & (48) \\
\hline
\end{tabular}

$* * * \mathrm{p}<.01 * * \mathrm{p}<.05 * \mathrm{p}<.10$ 
The Pure Relationship and Below Replacement Fertility

appear to influence uncertainty about fertility or below-replacement fertility preferences, a higher relationship risk profile substantially reduces the chances of desiring three or more children. The limited impact of relationship risk on fertility preferences raises the possibility that other aspects of what Lupton (1999b) terms "interpersonal risk", notably the direct risks associated with parenting could be relevant in accounting for both uncertain and belowreplacement fertility intentions.

On balance, this study has generated empirical results that highlight the potential value to social demography of key aspects of Anthony Giddens' social theory. Of special interest to demographers are elements of Gidden's pure relationship such as egalitarianism and risk, which, if fully operationalized could materially advance our understanding of the links between transformations in intimate relationships and in fertility behavior.

More generally, Giddens theory and concepts on modern family formation would seem to be a valuable resource for bringing together other theoretical strands in modern demography, and in the process, help to advance our understanding of the unprecedented behavioral shifts that define the second demographic transition.

\section{References:}

Beck, U. and E. Beck-Gernsheim. 1995. The Normal Chaos of Love. Cambridge: Polity Press.

Bongaarts, J. 1992. "Do reproductive intentions matter?" International Family Planning Perspectives. 18:102-108.

Giddens, A. 1990. The Consequences of Modernity. Stanford: Stanford University Press.

Giddens, A. 1991. Modernity and Self-Identity. Stanford: Stanford University Press.

Giddens, A. 1992. The Transformation of Intimacy. Stanford: Stanford University Press.

Giddens, A. 2000. Runaway World: How Globalization is Reshaping our Lives. New York: Routledge.

Hall, D.R. 1993. Reproductive individualism and divorce: An examination of attitudes and marriage dissolution in Canada. London, Ontario: Faculty of Graduate Studies, The University of Western Ontario, Canada 
David R. Hall

Hall, D.R. 1996. "Marriage as a pure relationship: exploring the link between premarital cohabitation and divorce in Canada," Journal of Comparative Family Studies 27(1): 1-12.

Hirschman, C. 1994. "Why fertility changes," Annual Review of Sociology 20: 203-233.

Jackson S., and Sue Scott. 1999. Risk anxiety and the social construction of childhood," in D. Lupton (ed.) Risk and Sociocultural Theory. Cambridge: University Press. Pp.86-107.

Lesthaeghe, R., and J. Surkyn. 1988. "Cultural dynamics and economic theories of fertility change," Population and Development Review 14(1): $1-45$.

Lesthaeghe, R. 1995. "The second demographic transition in Western countries: An interpretation," in K. O. Mason and A. M. Jensen (eds.) Gender and Family Change in Industrialized Countries. New York: Oxford University Press. Pp.17-62.

Lesthaeghe, R. 1998. "On theory development: applications to the study of family formation," Population and Development Review 24(1): 1-14.

Lupton, D. 1999a. "Risk and the ontology of pregnant embodiment," in D. Lupton (ed.) Risk and Sociocultural Theory. Cambridge: University Press. Pp.59-85.

Lupton, D. 1999b. Risk. London: Routledge.

Mills, M. 2000. The Transformation of Partnerships. Amsterdam: Thela Thesis Population Studies Series.

Radecki, S. and L. Beckman. 1992. Determinants of child-bearing intentions of low-income women: attitudes versus life circumstances. Journal of Biosocial Science 24: 157-166.

Tan, P.C., and Nai Peng Tey. 1994. "Do fertility intentions predict subsequent behavior? Studies in Family Planning. 25: 222-231.

Thronton, A., William Axinn and Daniel H. Hill. 1992. "Reciprocal effects of religiosity, cohabitation, and marriage." American Journal of Sociology 98: 628-651. 
The Pure Relationship and Below Replacement Fertility

Thomson, E. and Jan Hoem. 1996. "Couple childbearing plans and births in Sweden." Paper presented at the annual meetings of the Population Association of America, New Orleans, LA.

Van De Kaa, D.J. 1987. "Europe's Second Demographic Transition", Population Bulletin 42(1): 1-59.

Wallerstein, J. J. Lewis and S. Blakeslee. 2000. The Unexpected Legacy of Divorce. New York: Hyperion.

Wu, Z. and H. Wang. 1998. "Third birth intentions and uncertainty in Canada," Social Biology 45: :96-112. 